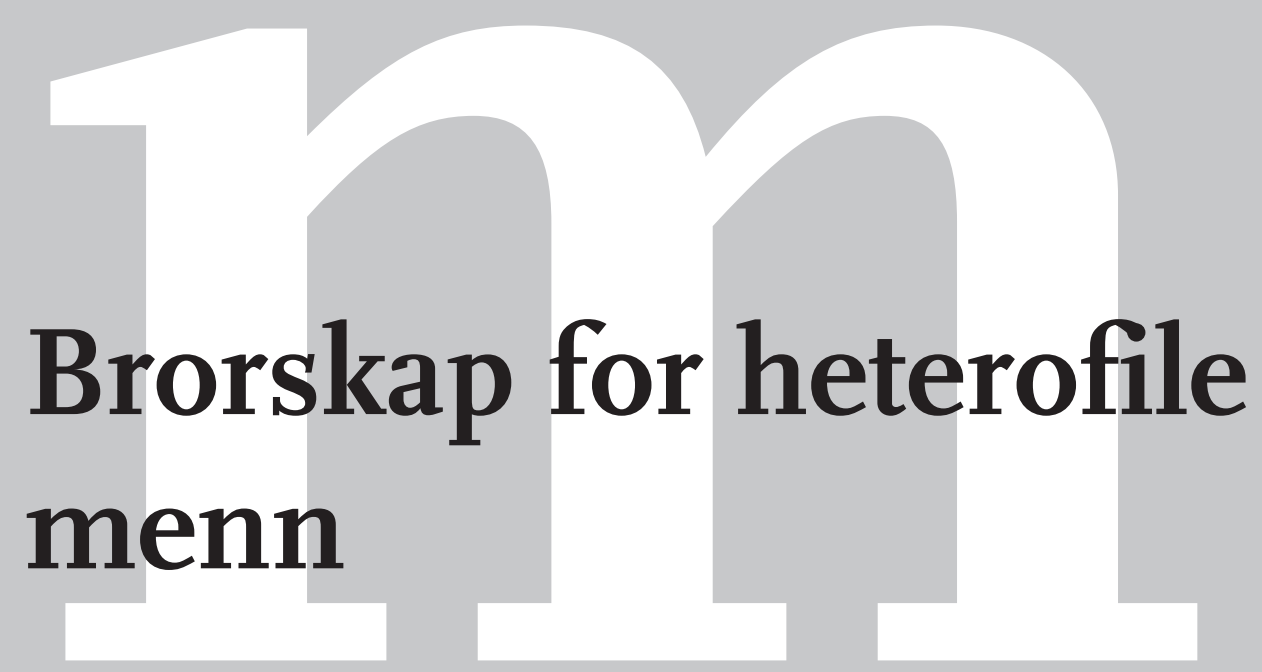

Lederne i DET MUSLIMSKE BRORSKAPET i Egypt insisterer på at de er moderne og vil arbeide innenfor demokratiets rammer. Kvinnelige presidenter og homofile kan de imidlertid ikke akseptere.

Anders Somme Hammer er journalist i Dagsavisen. anders.hammer@dagsavisen.no 
brorskapet: Det er vanskelig å danne seg et klart bilde av hva organisasjonen virkelig mener om en del grunnleggende samfunnsspørsmål. Selv proklamerer brorskapet to grunnpilarer:

I. Arbeidet for at sharia skal gjennomsyre staten så vel som samfunnet for øvrig.

2. Arbeidet for at de muslimske landene, først og fremst i Midtøsten, forenes og frigjøres fra utenlandsk imperialisme.

\section{Uenigheter og uklarheter}

I Egypt er det som oftest frykten for at brorskapet vil etablere et religiøst diktatur som debatteres. Organisasjonen ble formelt stemplet som ulovlig i i954, men har uformelt fått drive sitt organisasjonsarbeid - bare avbrutt av arrestasjoner og avslag på søknader om formell godkjenning.

TEKST: Anders Sømme Hammer

DET MUSLIMSKE BRORSKAPET ble etablert $\mathrm{i}$ I928, og har fungert som en inspirasjonskilde for den islamske bevegelsen over hele verden de siste 75 årene. Brorskapet regnes i dag som Egypts største opposisjonsbevegelse. De får ikke lov til å danne sitt eget politiske parti, men de I6 uavhengige representantene i nasjonalforsamlingen, som er blitt valgt inn under brorskapets slagord: "Islam er løsningen”, gjør organisasjonen til den største samlede politiske opposisjonsgruppen i Egypt. Det er imidlertid i moskeer, yrkesorganisasjoner og gjennom sitt utstrakte sosiale arbeid ved egne sykehus, skoler og direkte økonomiske støtte til fattige de først og fremst markerer seg og samler støtte i folket.

På tross av deres sentrale posisjon er det knyttet mye usikkerhet til Det muslimske
Tidlig på ı990-tallet ble Egypt skaket av angrep på den kristne minoriteten og turister. Siden attentatet mot president Anwar Sadat i I98I har egypterne levd under unntakstilstand, og det var forholdsvis enkelt for president Hosni Mubarak å stramme grepet ytterligere og peke ut Det muslimske brorskapet som en "ulovlig organisasjon" med bånd til "ekstremistiske grupper". Rett for valget i I995 ble flere hundre brorskapsmedlemmer arrestert med henvisning til at de utgjorde en sikkerhetstrussel som prøvde å mobilisere folket mot regimet. 6i medlemmer ble dømt til fengsel i opptil fem år. Liknende arrestasjonsrunder har fortsatt fram til i dag - dog i et litt mindre omfang.

Også i Norge forbindes brorskapet jevnlig med vold og terrorisme. Senest i en kronikk i Aftenposten tirsdag 3. februar 2004 omtaler forfatteren Walid al-Kubaisi brorskapet som mor til "alle terrororganisasjoner som al-Qaida, Jihad, Hamas, [og] 
Den islamistiske algeriske redningsfronten”. I et intervju i Dagsavisen lørdag 7 . februar, karakteriserer så journalist-aktivisten Hege Storhaug Det muslimske brorskapet som de "voldelige islamistene" (for øvrig i selskap med “al-Qaida” og “Mulla Krekar").

På tross av arrestasjoner og dokumenterte tilfeller av tortur og annen trakassering, har brorskapet de siste tiårene valgt å unngå direkte kon-

\section{mom \\ - I stygge drapssaker bør ikke kvinnen lede rettssaken fordi hennes følsomhet kan påvirke utfallet.}

frontasjoner med myndighetene i Egypt. "Vår tid vil komme", og “vi må bygge islam nedenfra”, er hyppige utsagn i samtaler med brorskapets medlemmer. De presenterer seg selv som islamister som gjennom demokratiske kanaler vil samle støtte for full implementering av sharia i det egyptiske samfunnet. Brorskapet hevder de ikke har brukt voldelige virkemidler de siste 30 årene.

Disse utsagnene illustrerer noe av usikkerheten rundt brorskapet. Utstyrt med en rekke spørsmål om organisasjonens holdninger dro jeg i januar i år til Kairo for å snakke med representanter for brorskapet om blant annet kvinner og homofili.

\section{Hijab-bråk}

2004 fikk en pangstart i Egypt etter at sjeik Mohamed Sayed Tantawi ved det islamske høysete al-Azhar-universitetet erklærte at Frankrike som et ikke-muslimsk land er i sin fulle rett til å forby hodeplagget hijab. Det muslimske brorskapet hisset seg opp og mente uttalelsen var nok et eksempel på at sjeik Tantawi er president Mubaraks marionett. Parlamentarisk leder for brorskapet Mohamed Morsy al-Ayat tok initiativet til en oppfordring til de andre lærerne ved al-Azhar om å ta avstand fra Tantawis utspill, og slå fast at det var " $i$ strid med islam".

- Ingen ba Tantawi om å gå til angrep på Frankrike, men han burde ikke sagt at hijab er valgfritt, forklarer al-Ayat.

- Hijab er ikke bare et religiøst symbol som det kristne korset og jødenes kalott. Hijab er obligatorisk. Det står i Koranen at kvinner skal dekke til hodet og kroppen, og det burde ikke være et problem for noen. Dette går verken på bekostning av kvinnens eller noen andres frihet.

- Men er det ikke undertrykkende å hevde at hijab er obligatorisk?

- Nei, hvorfor skulle det være det? Dette er ordre fra Allah. Hijab er bra for kvinnen. Den viser tilhørighet til Allah og mannen. al-Ayat får støtte av generalsekretær i advokatenes yrkesorganisasjon Ahmed Seif al-Islam Hassan al-Banna. Han frykter et fransk forbud mot hijab vil være innledningen til en omfattende innskrenkning av muslimenes rettigheter.

- Du kan ikke nekte en mann å forsvare huset sitt, svarer han på spørsmål om hvorfor brorskapet har gått så hardt ut mot sjeik Tantawi. al-Banna mener at selvforsvar er den riktige forståelsen av begrepet jihad.

I det autoritære Egypt har mange tilhengere av brorskapet søkt politisk makt i yrkesorganisasjonene. De siste 20 årene har brorskapet lykkes med å oppnå sentrale verv i en rekke av yrkesorganisasjonene. I 
tillegg til å forsvare og kjempe for medlemmenes rettigheter, driver yrkesorganisasjonene et utstrakt politisk arbeid gjennom komiteer som kommer med uttalelser om innenriks- så vel som utenrikspolitiske saker. Generalsekretær alBanna mener han ville ha blitt valgt til styreleder i advokatenes yrkesorganisasjon hvis myndighetene hadde latt han få stille til valg. Som sønn av den legendariske grunnleggeren av brorskapet, Hassan alBanna, har den 70-årige al-Banna junior levd tett med bevegelsen. Våren 2004 legger han siste hånd på et trebindsverk om brorskapets historie.

\section{Bare mannlige presidenter}

I I994 innså Det muslimske brorskapet at de burde klargjøre sine standpunkter i forhold til en rekke politiske spørsmål. Rapporten "Muslim Women in the Muslim Society” er et resultat av dette arbeidet. Den sendes fortsatt ut fra hovedkontoret i Kairo, og lederne henviser til den når spørsmål om kvinnens stilling blir reist. Med utgangspunkt i denne rapporten ba jeg brorskapsmedlemmene utdype noen uklarheter. I rapporten står det at mannen har rett til å bestemme over kvinnen, men at dette har sine klare begrensninger: “... [S] uch a directing role is confined to the family alone and to matters between husband and wife and none other." Parlamentarisk leder for brorskapet Mohamed Morsy al-Ayatfinner det enkelt å forklare hvorfor mannen er best kvalifisert til å styre familien:

- Dette har med hans fysiske og psykiske kapasitet å gjøre. Det er naturlig at han i kraft av sin styrke tar ansvaret. Dette er ikke et spørsmål om frihet eller likhet bare fysiske realiteter. Menstruasjon, gra- viditet og fødsel forstyrrer kvinnen slik at hun ikke kan oppføre seg normalt. Det er viktig å understreke at kvinnen på mange måter er privilegert. Det er mannens oppgave å skaffe nok penger til familien, og kvinnen er økonomisk uavhengig.

I "Muslim Women in the Muslim Society" omtales presidentvervet bare med en setning: "The only public office that it is agreed that a woman cannot occupy is "the grand office" which is the presidency or head of state under our present system". Ifølge al-Ayat har også dette en enkel forklaring:

- Dette skyldes også menstruasjon og fødsler. En slik posisjon krever en helt spesiell evne til å ta de rette beslutninger. Kvinnene er mer følsomme enn menn. Amming og menstruasjon gjør at de ikke kan reagere normalt på ulike hendelser. De kunne for eksempel komme til å trykke på atombombeknappen i en presset situasjon. Presidentvervet krever mannens fysiske og psykiske overlegenhet. Dette er jo ikke noe spesielt. Vi prøver bare å være realistiske.

Ifølge al-Ayatkan kvinnene ellers inneha alle typer stillinger, bortsett fra at de ikke kan være dommere i spesielt alvorlige rettssaker.

- I stygge drapssaker med masse blod og slikt, bør ikke kvinnen lede rettssaken fordi hennes følsomhet kan påvirke utfallet, sier al-Ayat.

- Hvordan er kvinnene mer følsomme enn menn?

- Det har jeg jo allerede svart på. Det er naturbetinget. Det har med hennes fysiske og psykologiske struktur å gjøre. Kvinner er mer følsomme.

- Det er en del som ikke er enige i dette.

- Men slik er realitetene. Kvinner og menn er ulike, og noen ganger vil 
kvinnene reagere annerledes enn menn. al-Banna i advokatenes yrkesorganisasjon er redd for at en artikkel om brorskapets syn på kvinner og homofile ikke vil lykkes med å speile hvor "moderne” organisasjonen er. al-Banna tror forholdet mellom menn og kvinner må utvikle seg skrittvis:

- Dette må du se på historisk. I gamle dager var mannen helt overlegen, men da islam kom, fikk kvinnen det mye bedre. I ditt land kan mannen hjelpe kvinnen med oppvasken, slikt skjer ikke i Kuwait, SaudiArabia og Egypt. Men nå har enkelte menn begynt å hjelpe til med noe husarbeid, så det skjer forandringer også her. Det er ikke så lenge siden den egyptiske bonden nektet døtrene å gå på skole. Her har Det muslimske brorskapet gått foran: Vi sender jo kvinner til valg til nasjonalforsamlingen!

- Men en kvinne kan ikke bli president.

- Nei, det passer seg ikke. Hun har fått noen problemer fra naturens side. Kvinnen kan jo bli gravid og få barn og slikt virker forstyrrende. Da må hun hvile i mange måneder. En eldre kvinne kan jo kanskje passe bedre, men du kan jo ikke si at bare eldre kvinner kan bli president. Det er uansett viktigere å føde og ta ansvar for barna enn å styre landet.

- Men kan ikke mor og far dele på ansvaret for barna?

- De første årene har barnet mer bruk for moren fysisk så vel som psykisk. Innenfor islam er barna kvinnens ansvar, mens mannen må tjene penger. Hvis mannen og kvinnen får mer frihet, så svekkes familien som helhet. Spørsmålet blir derfor om vi skal prioritere frihet eller helhet. Innenfor islam prioriterer vi helheten.

al-Banna illustrerer helhetsperspektivet med et tenkt eksempel:

- Hvis en mann er hjemme alene og en venninne av kona kommer på besøk, så skal mannen bare be venninnen komme tilbake senere igjen. Hvis han inviterer henne inn, og de begynner å le og tulle, så kan jo kona bli mistenksom og sjalu. Samme prosedyre bør følges hvis en kamerat av mannen kommer på besøk og bare kona er hjemme.

- Men hvorfor kan mannen gi kvinnen ordre om hva hun ikke får lov til å gjøre?

- Innenfor familien trenger vi lover som regulerer de sårbare sidene. Mannen er jo pliktig til å betale for kona og barna, og da må han kunne forsikre seg om at det er hans egen sønn som han betaler for. Derfor er han i sin fulle rett til å kontrollere kvinnen.

al-Banna gir er par eksempler på hvordan mannen kan kontrollere kvinnen:

- Hvis han har mistanke om utroskap, kan han nekte henne å gå spesielle steder, eller for eksempel legge ned forbud mot å snakke med en mann som ser på henne på en spesiell måte.

- Men går ikke dette på bekostning av kvinnens frihet?

- Igjen, du må velge. Frihet eller enhet i familien? Du må se på helheten.

- Men hva hvis mannen er utro?

- Da blir det jo en annen manns ansvar å betale for barnet, sier al-Banna og ler.

\section{Ulike begrunnelser}

Den tidligere lederen av Det muslimske brorskapet Mohamad al-Ma' moun al-Hodhaibi døde i januar i år. Den nye lederen, Mohamed Mahdi Akef (75), var stresset da jeg traff han noen dager etter al-Hodhaibis begravelse. Akef ristet på hodet da jeg spurte om det er kvinnenes spesielle følsomhet som hindrer dem fra å bli presidenter. 
- Nei, nei, det er feil, sier Akef som ikke endrer mening når jeg refererer til hva de andre i brorskapet har sagt.

- Kvinner kan ikke bli president fordi islam forbeholder noen ritualer for lederen - kalifen. Kvinner kan ikke være imam og lede bønner, og hun kan ikke lede hæren. Det er forbeholdt mannen. Derfor kan hun ikke bli president.

- Så det er ikke fordi kvinnene er mer følsomme?

- Nei, nei. Hun kan jo bli statsminister. Dette dreier seg bare om at det er enkelte religiøse ritualer hun ikke kan lede, i tillegg til at hun ikke kan kommandere hæren, sier han.

Ifølge Akef er islam den religionen som i størst grad likestiller menn og kvinner. Han henviser for øvrig til rapporten "Muslim Women in the Muslim Society”.

\section{Forakter homofili}

Det muslimske brorskapet aksepterer ikke homofili, men har ikke sett behov for å stadfeste dette i en egen rapport. Parlamentarisk leder Mohamed Morsy al-Ayat mener spørsmålet om hvorfor man ikke aksepterer homofili er latterlig. Han ler høyt og lenge før han svarer.

- Dette har jo med menneskenaturen å gjøre. Dette er snakk om dyriske handlinger som er i strid med sivilisasjonen. Jeg kan ikke se noen grunn til at menn skal oppføre seg slik menn og kvinner oppfører seg sammen. Dette er et veldig rart spørsmål som ikke burde stilles. De homofile prøver å stoppe den menneskelige utviklingen. Homofili er ikke menneskelig. Jeg kunne skrevet hundrevis av sider om dette.

- Det er mange som vil si at det er umenneskelig å fordømme homofili.
Morsy ler igjen.

- Folk får si hva de vil. Det er latterlig. Du kan like gjerne spørre om kvinner burde ha seg med dyr.

Også Seif al-Islam Hassan al-Banna mener at homofili er naturstridig, men finner det vanskelig å begrunne svaret.

- Det er ikke alle spørsmål som har svar. Hvorfor liker jeg for eksempel en god lukt? Men det enkleste svaret kan være at dette er skitne relasjoner. Dette er en del av kulturen vår. Du kan spør hvem som helst. En sosialist eller en nasserist vil si det samme. Flertallet er blitt enige om å forby homofili.

Advokatenes yrkesorganisasjon ble på midten av I990-tallet satt under direkte kontroll av myndighetene. Myndighetene hevdet de grep inn på grunn av økonomiske misligheter, mens al-Banna mener overtakelsen skyldtes at yrkesorganisasjonen krevde at politiet skulle bli etterforsket for drapet på en mann tilknyttet terroristorganisasjonen Jihad.

- Uansett hvem man er, så mener vi at man har krav på en viss form for beskyttelse, sier al-Banna.

Han er imidlertid ikke enig $i$ at det er diskriminerende å forby homofili.

- Nei, hvis det er slik man skal se på det, så trenger vi jo ikke lover. Du kan ikke drepe en mann fordi du ikke liker ham. Jeg tror dette kommer til å være forbudt i fremtiden også. Det er ikke riktig. Hvor tror du aids kom fra?

\section{For kompliserte spørsmål}

Oppholdet i Kairo ble avsluttet hos den islamske kommentatoren Fahmi Howeidy. Han er kjent som en ivrig forsvarer av den islamske bevegelsen, men bruker også spalteplass til kritikk når han mener det er 
på sin plass. Howeidy sier at han ikke er med i brorskapet, men han har likevel blitt straffet for organisasjonens arbeid. Howeidys far var med på å stifte brorskapet. Da organisasjonen røk uklar med president Nasser i i954, ble også Howeidy fengslet. Han slapp ut igjen to år senere. Han var da atten år. Howeidy blir oppgitt når jeg spør om Det muslimske brorskapet har en rotete ideologi.

- Vestlige journalister kommer hit stadig vekk og stiller altfor detaljerte spørsmål. Det er etableringen av et demokrati som er det viktige her, spørsmål om likestilling blir ubetydelig i forhold.

Howeidy mener brorskapets kvinnesyn vil utvikles og endres hvis de kommer til makten. Når det gjelder homofili tror imidlertid Howeidy at alt vil forbli som før. Han mener hele det egyptiske samfunnet fordømmer homofili, og nevner dette som et eksempel på et av de tradisjonelle standpunktene som står i fare for å bli svekket gjennom vestliggjøringen.

\section{Undertrykking}

Det er ikke nødvendig å gå helt til Det muslimske brorskapet for å høre alternative tanker omkring likestilling og homofili i Egypt. Man skal lete lenge for å finne andre spørsmål som i like stor grad illustrerer ulikhetene mellom samfunnsdebatten i Egypt og Norge. Brorskapets uttalelser om likestilling og homofili tyder på at deres liberale motstandere - uavhengig av motiver - også i den nærmeste fremtiden vil kunne argumentere for at organisasjonen vil undertrykke og diskriminere enhver som ikke framstår som heterofil mann.
KILDER:

Abdel-Latif, Omayma: "Rules of engagement", i al-Ahram Weekly online, I8.-24. september 2003, http://weekly.ahram. org.eg./ 2003/656/eg6.htm

al-Hudaibi, Muhammad M.: «The Principles of Politics in Islam», Islamic inc., Kairo 2000

al-Hudaibi, Muhammad M.: «A Quiet Discussion on Heated Issues», al-Falah Foundation, Kairo 2000

al-Kubaisi, Walid: “Den sanne historien om slør og skaut i islam" i Aftenposten tirsdag 3. februar 2004

Amnesty International (2000): "Egypt: Muzzling Civil Society," I9.09.2000, http://web.amnesty.org/library/Index/engMDEI2O2I2000? OpenDocument\&of=COUNTRIES $\backslash$ EGYPT ?OpenDocument\&of=COUNTRIES $\mid$ EGYPT

Bari, Zohurul: «Re-emergence of the Muslim Brothers in Egypt», Lancers Books, New Delhi 1995

Elsady, Mohamed: "None of our business" i Cairo Times, Kairo, 8.-14. januar 2004

Hoffengh, Sissel: “Demokrakilsk” i Dagsavisen, Oslo, 7. februar 2004

Muslim Brotherhood: "Muslim Women in the Muslim Society" (udatert stensil fra I994 som deles ut ved Det muslimske brorskapets hovedkontor i Kairo.)

Shahine, Gihan: "Veiled dependency?” i al-Ahram Weekly online, 8.-I4. januar 2004, http://weekly.ahram.org.eg /2004/672/fr2.htm

Wickham, Carrie Rosefsky: «Mobilizing Islam», Columbia University Press, New York 2002

\section{- $f \cdot$}

